\title{
INDIAN TAX STRUCTURE - AN ANALYTICAL PERSPECTIVE
}

\author{
Dr. S. M. ALAGAPPAN, Ph.D \\ Associate professor in Commerce, Arumugam Pillai Seethai Ammal College \\ Tiruppattur, Sivagangai District - 630211, India
}

\begin{abstract}
Tax payment is mandatory for every citizen of the country. Taxation is an instrumental tool to procure resources for the government to enable it to formulate policy schemes for the overall development of the economy. Income tax plays an important role as a source of revenue and an effective measure of removal of economic disparity. Different objectives of taxation, each one of them desirable by itself, can pull in different directions. The state should formulate a comprehensive and cohesive tax system which can balance the different objectives in view of its own requirements and goals. The present paper is an attempt to study the present tax structure in India and the recent reforms undertaken.
\end{abstract}

Keywords: Direct taxes, Indirect taxes, tax collections, revenue, savings, economy.

Cite this Article: Dr. S. M. Alagappan, Ph.D, Indian Tax Structure - An Analytical Perspective, International Journal of Management, 10 (3), 2019, pp. 36-43. http://iaeme.com/Home/issue/IJM?Volume=10\&Issue $=3$

\section{INTRODUCTION}

Indian tax system has been unorganised, unregulated and unplanned due to historical reasons. India's alien rulers taxed the people to the benefit of their coffers and also for Royal luxuries of the state. Land revenue was the major part of income for the royal treasury. Other taxes used to be levied on adhoc basis. During the British rule, no effort was made for uniformity in the tax system. Vast differences were there between the tax policies of the native kings and the British provinces. Social justice, social welfare and economic development were not linked to tax system in anyway. After Independence, each and every aspect of Indian Tax System was studied thoroughly and all possible attempts were made to make the system equitable, just and economic, besides yielding adequate revenue to finance the administration and also cater to the needs of economic development.

The Indian constitution came into effect from $26^{\text {th }}$ January 1950. It is federal in structure. Clear distinction is made between sources of revenues of union and states in which the residual power belongs to the centre. The constitution is supreme in India and it is the source for all laws. Union and states derive the power to levy and collect tax from the constitution. If any rule or law of the government is not according to constitution, it becomes illegal and void. According to Taxation Enquiry Commission, the division of tax powers and distribution of revenue resources between the centre and states can be termed as the 'Tax System'. 


\section{REVIEW OF LITERATURE}

Nishant Gauge and Katdare (2015) ${ }^{1}$ in the article, "Indian Tax Structure - An Analytical Perspective" identified the amount of revenue collected from different types of taxes over the period of 4 years. His study found that the amount collected from indirect taxes is nearly twice the amount collected from direct taxes. His study suggested that government should focus on structural reforms than policy reforms.

Sherline T.I (2016) ) ${ }^{2}$ in the research paper, "Indian Tax Structure and Relevance of GST" analysed the basic tax structure in India and the relevance of GST. This paper revealed that cascading tax revenues have differential impact on firms in the economy with relatively high burden on those not getting full offsets.

Pramod Kumar Pandey (2017) ${ }^{3}$ conducted a study titled, “The Impact of Indian Taxation system on its Economic Growth" to evaluate the impact of both direct and indirect taxes on economic growth of India. The study reveals that there is lack of coordination between the Central board of direct taxes and Central board of Excise and Customs and thus it is highly needed that these two departments must be consolidated into one.

\section{Note}

1. Nishant Gauge and Katdare, "Indian Tax Structure - An Analytical Perspective", International Journal in Management and Social Science", ISSN: 2321-1784, Vol.03, Issue 09, Sep. 2015

2. Sherline T.I, "Indian Tax Structure and Relevance of GST", International Journal of Commerce, Business and Management< ISSN: 2319-2828, Vol.5, No.6, Nov-Dec 2016.

3. Pramod Kumar Pandey, "The Impact of Indian Taxation system on its Economic Growth", Scientific Society of Advanced Research and Social Change, ISSN 2349-6975, Vol.3, Issue 1, January-June 2017.

\section{NEED OF THE STUDY}

All the modern states in the post second world war era have realised that taxation is a powerful instrument with multiple applications. It can be used to reduce inequalities, to accelerate economic development, as a tool to regulate compensation, imports and exports, in addition to its basic objective of raising revenues. India offers a well-structured tax system for its population. Taxes are the largest source of income for the government. This money is deployed for various purposes and projects for the development of the nation. Indian taxation system has undergone tremendous reforms during the last decade. The tax rates have been rationalised and tax laws have been simplified resulting in better compliance, ease of tax payment and better enforcement. As taxation structure plays an important role in country's development, there is always need for study of the taxation structure to make the taxation structure more simple than earlier.

\section{STATEMENT OF THE PROBLEM}

As early as 1917, Prof.Seligman remarked, "the tax reform is every where in air'. In India also, the need for reforming tax system was realised early and a number of committees were appointed at various times to examine different aspects of taxation. GST has brought in a structural change in the indirect tax system in India. What is needed now is a similar reform on the direct tax front. Many problems like multiplicity of taxes, dominance of indirect taxes, adhocism, bias in incidence of taxes, complexity and corruption, imbalance in tax system, lack of coordination, lack of built-in-elasticity, squandering away of resources, administrative inefficiency and corruption show that Indian taxation system requires some major reforms in the future ahead, addressing all these problems. 


\subsection{OBJECTIVES}

- To study the tax structure in India

- To identify the amount of revenue collected from different types of taxes

- To analyse the revenues from taxable sources and non taxable sources

- To identify the amount spent for tax collection

\section{RESEARCH METHODOLOGY}

This study is purely based on secondary data. Various figures are obtained from the different websites of Government of India. Other secondary sources include text books, journals, on-line published articles, information from the local newspapers and internet search engines, unpublished articles.

\subsection{CLASSIFICATION OF TAXES}

The tax structure in India is divided into direct and indirect taxes. Direct taxes are levied on taxable income earned by individuals and corporate entities, the burden to deposit taxes is on the assesses themselves. On the other hand, indirect taxes are levied on the sale and provision of goods and services respectively and the burden to collect and deposit taxes is on the sellers instead of the assesses directly.

Some of the direct taxes prevailing in India:

- Income tax

- Corporation tax

- Dividend tax

- Capital gains tax

- Wealth tax

- Gift tax

- Estate duty or Inheritance tax

- Land revenue

- Agricultural Income tax

- Professional tax

Some of the indirect taxes prevailing in India:

GST is an Indirect Tax which has replaced many Indirect Taxes in India. The Goods and Service Tax Act was passed in the Parliament on 29th March 2017. The Act came into effect on 1st July 2017; Goods \& Services Tax Law in India is a comprehensive, multi-stage, destination-based tax that is levied on every value addition.

Indirect taxes which are not included in GST:

- Basic Customs duty

- Exports duty

- Road \& Passenger tax

- Property tax

- Stamp duty

- Electricity duty 


\subsection{DIFFERENCES BETWEEN DIRECT TAX AND INDIRECT TAX}

- Incidence of direct tax is directly on the taxpayer. Incidence of indirect tax is on traders or manufacturers, but shifted to buyers of goods or services later on.

- Shifting of burden is not easy in case of direct taxes and tax payer has to bear the tax. The indirect tax can be shifted to other individuals.

- In case of direct taxes, scope for evasion is high through falsification of accounts and suppression of income. Scope for tax evasion is low in case of indirect taxes, as the tax forms part of product or service price.

- Direct tax may reduce inflation, whereas indirect tax may enhance inflation.

- Direct taxes adversely affect the taxpayers' ability to save and invest. In case of indirect taxes, savings and investment may be increased due to reduction in the usage of non essential goods or services.

- Direct taxes are progressive taxes which reduce inequalities, whereas indirect taxes are regressive taxes which enhance inequalities.

- In case of indirect taxes, by heavily taxing harmful articles such as cigarettes, liquors etc., the government can divert the purchasing power of people towards the useful articles and thereby create beneficial consumption pattern.

- Direct taxes are usually complex with a lot of exemptions, procedures and provisions which may necessitate assistance of professional accountants and auditors involving higher administrative costs, whereas indirect taxes involve lesser administrative costs due to convenient and stable collections.

- Indirect taxes have a wider coverage as all members of the society are taxed through the sale of goods and services, while direct taxes are collected only from people in respective tax brackets.

Indirect taxes allow the government to expect stable and assured returns and brings into its fold almost every member of the society - something which the direct tax has been unable to do. But, both direct and indirect taxes are important for the country as they are intricately linked with the overall economy. As such, collection of these taxes is important for the government as well as the well-being of the country.

\subsection{ANALYSIS OF INDIAN TAX STRUCTURE}

Following table no. 1 shows the details of the amount raised from direct taxes and indirect taxes by both central and state governments.

Table 1 REVENUE RECEIPTS in Rs.crore

\begin{tabular}{|c|c|c|c|c|}
\hline & $\mathbf{2 0 1 3 - 1 4}$ & $\mathbf{2 0 1 4 - 1 5}$ & $\mathbf{2 0 1 5 - 1 6}$ & $\mathbf{2 0 1 6 - 1 7}$ \\
\hline $\begin{array}{c}\text { Revenue receipts }- \\
\text { Direct tax }\end{array}$ & 648966 & 703508 & 763454 & 862077 \\
\hline $\begin{array}{c}\text { Revenue receipts }- \\
\text { Indirect tax }\end{array}$ & 1230177 & 1336518 & 1620967 & 1822307 \\
\hline
\end{tabular}

Source: Public finance statistics, Ministry of Finance, 2016-17 
Dr. S. M. Alagappan, Ph.D

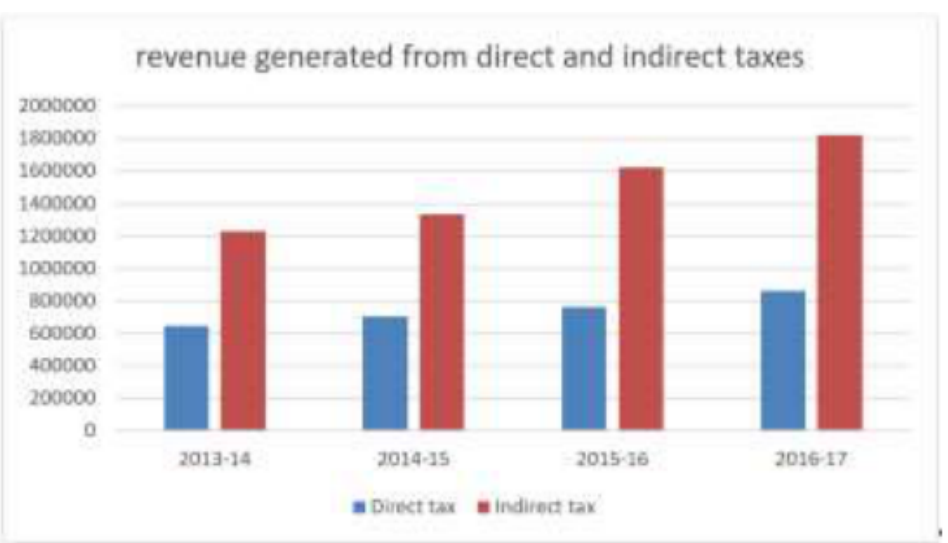

Figure 1

Interpretations:

From the above graph, it is seen that the amount of revenue received from indirect taxes is almost double the revenue received from direct taxes. Hence it can be observed that there is more dependence on indirect taxes for revenue collection.

Table 2 PROPORTION OF DIFFERENT DIRECT TAXES FOR THE YEAR 2016-17

\begin{tabular}{|c|c|c|}
\hline Name of Direct Tax & $\begin{array}{c}\text { Amount collected } \\
\text { (Rs. Crore) }\end{array}$ & $\begin{array}{c}\text { Percentage share in total } \\
\text { direct tax (\%) }\end{array}$ \\
\hline Corporation tax & 493924 & 57.30 \\
\hline Taxes on income & 345776 & 40.11 \\
\hline Estate duty & 0 & 0 \\
\hline Interest tax & 0 & 0 \\
\hline Wealth tax & 0 & 0 \\
\hline Gift tax & 0 & 1.63 \\
\hline Land revenue & 14090 & 0.01 \\
\hline Agricultural tax & 116 & 0.01 \\
\hline Hotel receipts tax & 89 & 0 \\
\hline Expenditure tax & 0 & 0.94 \\
\hline Others* & 8083 & 0 \\
\hline
\end{tabular}

* includes taxes on professions, trades, employment and non-urban immovable properties etc. Source: Public finance statistics, Ministry of Finance, 2016-17

proportion of different direct taxes during 2016-17

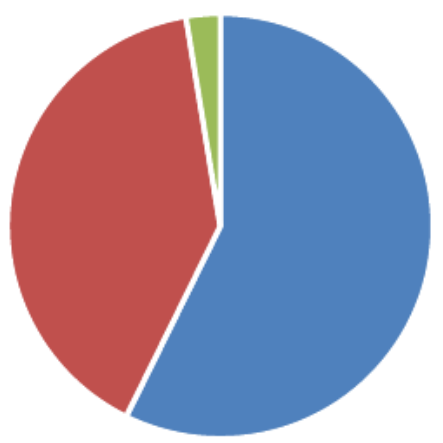

- corporation tax - taxes on income $\mid$ all other sources 
Interpretations:

Table No.2 reveals that the major portion of revenue from direct taxes comes under the heads Corporation tax (57.30\%) and Taxation on Income (40.11\%). All other sources constitute upto $2.59 \%$ of total direct taxes.

Table 3 PROPORTION OF DIFFERENT INDIRECT TAXES FOR THE YEAR 2016-17

\begin{tabular}{|c|c|c|}
\hline Name of Direct Tax & $\begin{array}{c}\text { Amount collected } \\
\text { (Rs. Crore) }\end{array}$ & $\begin{array}{c}\text { Percentage share in total } \\
\text { direct tax (\%) }\end{array}$ \\
\hline Customs duty & 230000 & 12.62 \\
\hline Union excise duties & 317860 & 17.44 \\
\hline Service tax & 231000 & 12.68 \\
\hline State excise duty & 125902 & 6.91 \\
\hline Stamp \& registration fees & 113122 & 36.81 \\
\hline General sales tax & 670875 & 3.00 \\
\hline Taxes on vehicle & 54593 & 0.16 \\
\hline Entertainment tax & 2998 & 1.48 \\
\hline Taxes on goods and passengers & 26974 & 1.80 \\
\hline Taxes and duty on electricity & 32785 & 0.07 \\
\hline $\begin{array}{c}\text { Taxes on purchase of sugarcane } \\
\text { (including cess on sugarcane) }\end{array}$ & 1258 & 0.82 \\
\hline others & 14940 & \\
\hline
\end{tabular}

* includes taxes on professions, trades, employment and non-urban immovable properties etc. Source: Public finance statistics, Ministry of Finance, 2016-17

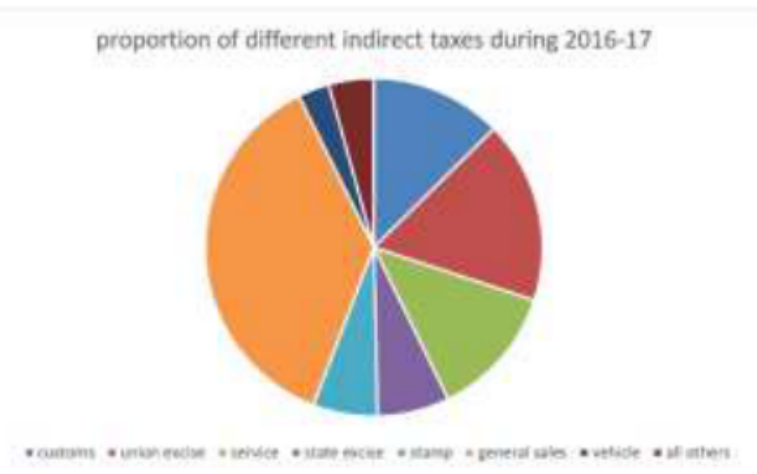

Figure 3

Interpretations:

It is interpreted from table no.3 that the major portion of revenue from indirect taxes is generated by the head General sales tax (36.81). The other heads which generate moderate revenue are union excise $(17.44 \%)$, service tax $(12.68 \%)$, customs duty $(12.62 \%)$. The other heads like state excise $(6.91 \%)$, stamp \& registration $(6.21 \%)$ and taxes on vehicle $(3 \%)$ generate lower revenues. All other sources constitute upto $4.33 \%$ of total indirect taxes.

Table 4 TAX COLLECTION CHARGES

\begin{tabular}{|c|c|}
\hline Year of collection & Amount (Rs. Crore) \\
\hline $21013-14$ & 29995 \\
\hline $2014-15$ & 32563 \\
\hline $2015-16$ & 36092 \\
\hline $2016-17$ & 40682 \\
\hline
\end{tabular}

Source: Public finance statistics, Ministry of Finance, 2016-17 


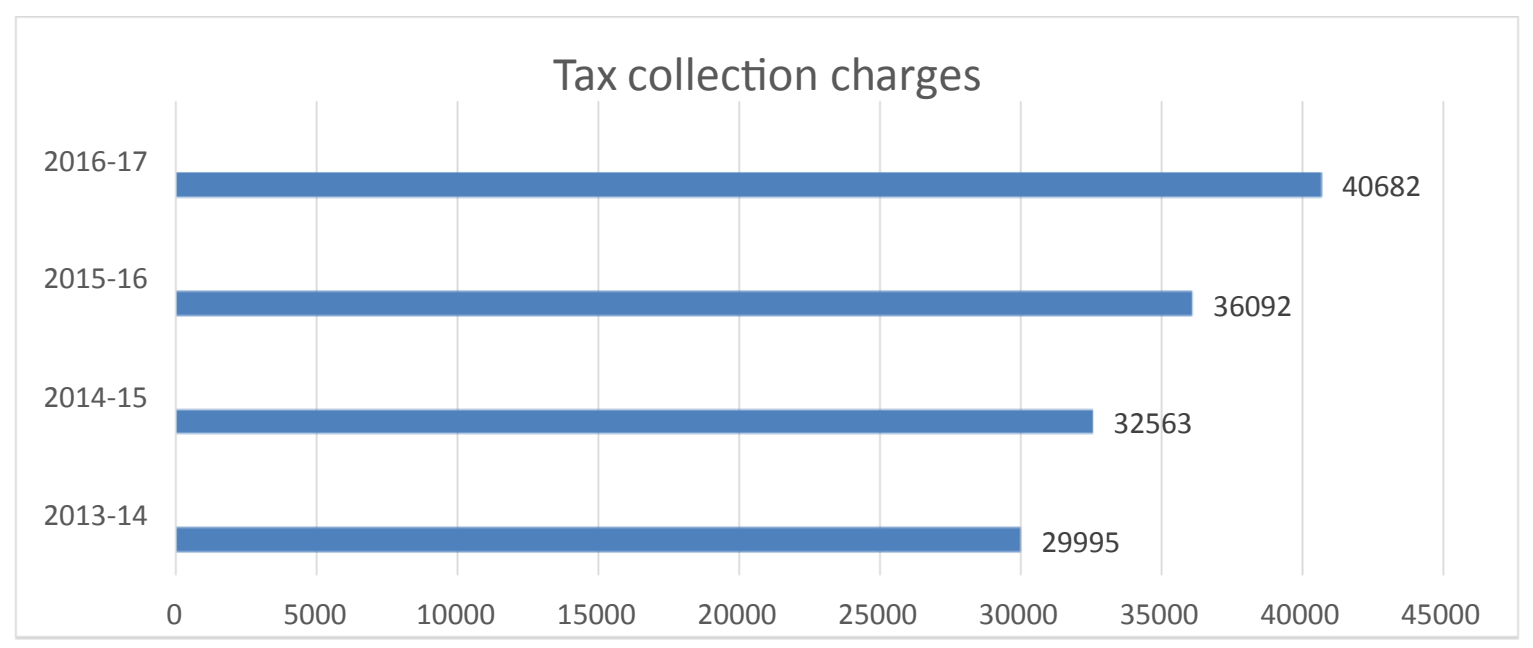

Figure 4

Interpretations;

From the figure no.4, it could be seen that the government is spending huge expenses for collection of taxes and the amount of expenses made on collection goes on increasing from year to year.

Table 5 TAX REVENUE and NON TAX REVENUE in Rs.crore

\begin{tabular}{|c|c|c|c|c|}
\hline & $\mathbf{2 0 1 3 - 1 4}$ & $\mathbf{2 0 1 4 - 1 5}$ & $\mathbf{2 0 1 5 - 1 6}$ & $\mathbf{2 0 1 6 - 1 7}$ \\
\hline Tax Revenue & 1879143 & 2040027 & 2384421 & 2684384 \\
\hline Non tax revenue & 280377 & 283622 & 373839 & 459338 \\
\hline
\end{tabular}

Source: Public finance statistics, Ministry of Finance, 2016-17

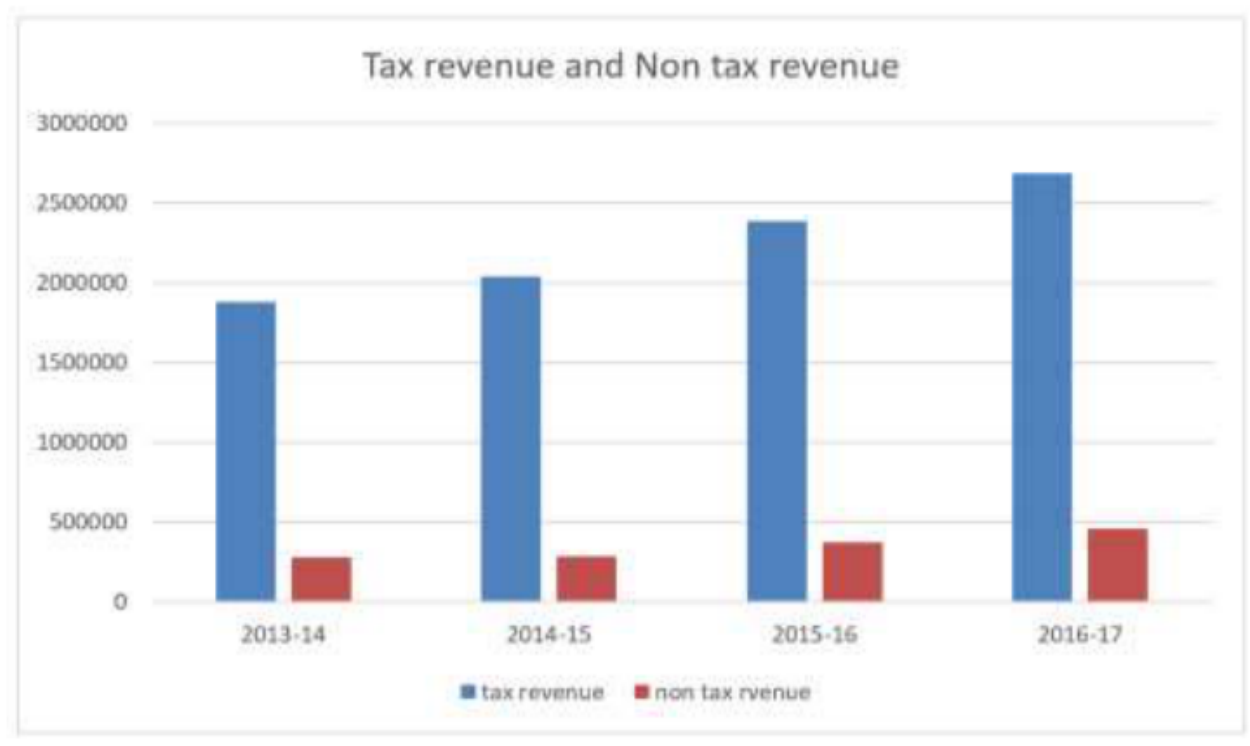

Figure 5

Interpretations:

From the above graph, it is seen that the amount of tax revenue is almost six times greater than the revenue received from non tax entities. Hence it can be observed that taxation can be used as an effective tool to achieve higher levels of economic development and employment. 


\section{FINDINGS}

- The amount of revenue received from indirect taxes is almost double the revenue received from direct taxes. Hence it can be observed that there is more dependence on indirect taxes for revenue collection.

- The major portion of revenue from direct taxes comes under the heads Corporation tax $(57.30 \%)$ and Taxation on Income (40.11\%). All other sources constitute upto $2.59 \%$ of total direct taxes.

- The major portion of revenue from indirect taxes is generated by the head General sales tax (36.81). The other heads which generate moderate revenue are union excise $(17.44 \%)$, service tax $(12.68 \%)$, customs duty $(12.62 \%)$. The other heads like state excise $(6.91 \%)$, stamp \& registration $(6.21 \%)$ and taxes on vehicle $(3 \%)$ generate lower revenues. All other sources constitute upto $4.33 \%$ of total indirect taxes.

- The government is spending huge expenses for collection of taxes and the amount of expenses made on collection goes on increasing from year to year.

- The amount of tax revenue is almost six times greater than the revenue received from non tax entities.

\section{CONCLUSION}

A baneful feature of the Indian Tax system is the lack of administrative efficiency. There is no coordination between the taxes to allow a well-organised, planned and co-ordinated tax system to evolve. In India, the rate of direct tax is very high, but the contribution to the total tax revenue is very low. Steps must be taken to curb tax evasion and tax avoidance. The exemption limit has been raised from time to time, but the levels of national and per capita incomes have failed to increase proportionately. India's new Goods and Serviecs Tax marks a significant step towards achieving the county's long-held goal of economic liberalization.

\section{REFERENCES}

[1] A Jha, "Tax Structure in India and effect on corporates", International Journal of Management and Social Sciences research, 2(10), 2013, pp 80-82

[2] Vineet Singh and Abhinna Srivastava. Direct Tax Revenue: A Case Study of Central V/S State Government. International Journal of Management, 6(12), 2015, pp. 83-88

[3] H Kumat, "Taxation Laws of India - An Overview and Fiscal Analysis 2013-14", Indian Journal of Applied Research, Jan 2014, 4(9),pp 82-84

[4] Vineet Singh and Abhinna Srivastava. Indirect Tax Revenue - An Assessment of Central V/S State Government. International Journal of Management, 7(3), 2016, pp. 12-17.

[5] Hemant Singh, "History of Taxation in India", www.jagranjosh.com, Oct 112017

[6] Vineet Singh and Abhinna Srivastava. Indirect Tax Revenue - An Assessment of Central V/S State Government. International Journal of Management, 7(3), 2016, pp. 12-17

[7] M.M. Sury, "Tax System in India: Evolution and Present Structure", New Century publications, 2015 